\title{
Preparation of iodate of potash
}

\section{Mellon}

To cite this article: M. Mellon (1841) Preparation of iodate of potash, Philosophical Magazine Series 3, 19:124, 334-335, DOI: 10.1080/14786444108650430

To link to this article: http://dx.doi.org/10.1080/14786444108650430

册 Published online: 01 Jun 2009.

Submit your article to this journal $\pi$

Џll Article views: 2

Q View related articles $₫$ 
the lactate of lime formed immediately crystallizes in perfectly white mammillated masses, and from this the lactic acid is procured by the well-known processes.

It is evident, observe the authors, that lactic acid may be saturated by other bases, and they state that a chemical manufacturer has prepared this acid from the sour water of starch-makers, by saturating it with carbonate of lime.-Journal de Pharmacie, xxvii. 341.

\section{PREPARATION OF FORMIC ATHER.}

According to Wöhler, the following process yields formic æther in large quantity, and very readily : put into a retort ten parts of starch and 37 parts of peroxide of manganese, intimately mixed in very fine powder; add to them a mixture of 30 parts of sulphuric acid, 15 parts of highly rectified spirit of wine, and 15 parts of water; the mixture is to be gently boiled, and distillation continued until the product contains no æther. In order to separate the water and the alcohol, a sufficient quantity of chloride of calcium is to be dissolved in the product, and distillation is to be performed in a water-bath; the purification is to be completed by a second rectification in the same manner.

M. Wöhler states, that in the numerous experiments which $M$. Kolbe made on this subject at his request, appearances presented themselves which probably indicate the presence of a peculiar substance in this æther, requiring fresh experiments for elucidation: when the fragments of fused chloride of calciurn have been for some time in contact with the ether which has been once rectified, and are partly dissolved, it becomes of a deepish yellow colour, and deposits small, very fine colourless crystals on the sides of the vessel. In general the colour disappears after a certain time; it is probably owing to chloride of iron; and probably also the crystals are a compound of chloride of calcium and alcohol, which are soluble in formic ather, and may crystallize from it.-Journal de Pharmacie, tom. xxvii. p. 91 .

\section{PREPARATION OF IODATE OF POTASH. BY M. MELLON.}

When cold no action takes place between the above-named substances; but if to chlorate of potash about three or four times its weight of distilled water be added, and then heated to ebullition, iodine added to the solution disappears in considerable quantity; the liquor is colourless, and remains so until the equivalent of iodine is exceeded; after this the liquor becomes yellow and then brown; and, as a final result, there are obtained neutral iodate of potash and chloride of iodine, with greater or less excess of the latter. If the mixture be evaporated to dryness, the chloride of iodine is disengaged, and the iodate of potash remains pure.

If the action of the iodine on the chlorate be stopped before an equivalent of the jodine is added, the liquor even then contains iodate of potash, and also chlorate [chloride ?] of iodine, corresponding unquestionably to iodic acid; for if the liquor be strongly heated, 


\section{Meteorological Observations.}

chlorine is disengaged, and there remains chloride of iodine, which gives a precipitate of iodine with carbonate of potash.

According to M. Mellon, the formation of chloride of iodine explains the reaction that occurs: the iodine attracts the chlorine of the chlorate, whilst the greater affinity of the iodine for the oxygen, and the greater cohesion of the iodate, cause the iodine to enter into the chlorate instead of the chlorine. The action M. Mellon represents thus : $5 \mathrm{CIO}^{5}, \mathrm{KO}+61=5 \mathrm{I} \mathrm{O}^{5}, \mathrm{KO}+\mathrm{I} \mathrm{CI}^{5}$.

Journal de Pharmacie, tom. xxvii, p. 102.

\section{PROFESSORSHIP OF GEOLOGY, UNIVERSITY COLLEGE, LONDON.}

We have great pleasure in recording the establishment of a Chair of Geology in University College, and that Thomas Webster, Esq., formerly Secretary to the Geological Society, has been appointed to occupy it.

Professor Webster's Course on Geology at the College, consisting of Thirty Lectures, will commence on the first 'Tuesday in February 1842 , and will be divided into three parts.

1. The description of such simple minerals as enter essentially into the composition of rocks.

2. Geology, properly so called; or the characters and superposition of the strata composing the crust of the globe, together with an account of the various phænomena exhibited by them.

3. The application of the above subjects to the useful arts.

\section{METEOROLOGICAL OBSERVATIONS FOR AUG. 1841.}

Chiswick.-A ugust 1. Slight rain : cloudy and fine. 2. Fine with clouds : rain. 3. Hazy: cloudy and mild: rain. 4. Cloudy and fine, 5. Fine : slight rain. 6, 7. Fine. 8. Rain : cloudy and fine. 9. Very fine. 10. Very fine : rain. 11. Stormy and wet. 12. Fine. 13. Cloudy. 14. Rain : showery : clear at night. 15-17. Cloudy and fine. 18. Hazy : fine. 19, 20. Very fine. 21. Cloudy. 22. Cloudy : slight rain. 23. Rain : cloudy and fine. 24. Showery: clear. 25. Drizzly. 26. Hazy and mild. 27. Heavy dew : cloudy and hot. 28-30. Foggy in the mornings: very fine : evenings clear. 31. Overcast and fine.

Boston.-August 1. Fine: rain P.M. 2, Fine. 3, Cloudy: rain P.M. 4. Fine: rain early A.M. 5. Cloudy : rain P.M. 6. Cloudy and stormy. 7. Cloudy : rain p. s. 8, 9. Cloudy, 10. Fine. 11. Cloudy : rain early A.M.: rain P.M. 12. Stormy. 13. Cloudy, 14. Cloudy: rain early A.M. 15, 16. Cloudy. 17. Fine: rain P.M. 18, 19. Fine. 20. Fine : thermometer $77^{\circ}$ half-past two P.M. 21. Fine: rain A.M. 22. Fine. 23, 24. Fine: rain early A.M. 25. Rain : rain early A.M. 26. Cloudy : thermometer $75^{\circ}$ three-quarters past two P.M. 27. Fine : thermometer $75^{\circ}$ quarter -past eleven A.m. 28, 29. Fine. 30, 31. Cloudy. Applegarth Manse, Dumfries-shire-August 1. Fair, but cool and cloudy. 2. Fair and fine. 3. Wet A.M. : cleared and was fine, 4. Fair and fine. 5. Rain all day. 6. Wet A.m. : cleared and was fine. 7. Wet, slightly. 8. Fine though showery : thunder. 9. Wet A.M. : became fine. 10. Showery. 11. Fair. 12. Showery all day. 13. Partial showers. 14. W't A.M. : became fine. 15. Fine till P.M.: then rain. 16. Wet A.M. : cleared p.m. 17. Fair throughout. 18. Fair A.M. : wet P.M. 19. Fair and warm: air electrical. 20. Wet nearly all day : thunder. 21. Wet R.M. : flood. 22. Fine and fair, 23. Occasional slight showers. 24. Wet P.M. and evening : thunder. 25. Showery. 26. Rain early A.M. : cleared. 27. Fine : one shower a.m. 28. Wet morning : cleared, 29. Fine but cloudy, 30. Wet all day. 31. Fair and fine. 